\title{
YEAST COMMUNITIES IN TWO ATLANTIC RAIN FOREST FRAGMENTS IN SOUTHEAST BRAZIL
}

\author{
Raphael S. Pimenta ${ }^{1 *}$; Priscila D. D. Alves ${ }^{2}$; Gabriel M. F. Almeida ${ }^{2}$; Juliana F.M Silva ${ }^{1}$; Paula B. Morais ${ }^{1}$; \\ Ary Corrêa Jr. ${ }^{2}$; Carlos A. Rosa ${ }^{2}$
}

${ }^{1}$ Laboratório de Microbiologia Ambiental e Biotecnologia, Universidade Federal do Tocantins, Palmas, TO, Brasil; ${ }^{2}$ Departamento de Microbiologia, Universidade Federal de Minas Gerais, Belo Horizonte, MG, Brasil.

Submitted: January 25, 2008; Returned to authors for corrections: March 01, 2008; Approved: February 25, 2009.

\begin{abstract}
We studied the yeast communities associated with fruits, mushrooms, tree exudates, and flies of the genus Drosophila, in two Atlantic Rain Forest fragments in state of Minas Gerais, Brazil. A total of 456 samples were collected from Rio Doce State Park and 142 from Ecological Station of Universidade Federal de Minas Gerais. From these samples, 608 yeast isolates were obtained, belonging to 71 different species. Among the yeasts isolated from Rio Doce State Park, 17 isolates were recovered from fruits, 12 from mushrooms, 13 from tree exudates, and 299 from Drosophila spp. In the Ecological Station of Universidade Federal de Minas Gerais, 24 isolates were recovered from fruits and 243 from Drosophila spp. Distinct communities of yeast were observed in Drosophila flies, fruits, mushrooms and tree exudates. The highest number of yeast species was recovered from Drosophila flies suggesting that flies are the natural vectors of these microorganisms.
\end{abstract}

Keywords: Yeast communities, Drosophila, fruits, mushrooms, tree exudates, Atlantic Rain Forests.

\section{INTRODUCTION}

The distribution and specificity of yeast communities are related to the composition of nutrients present in the substrate, presence of inhibitory compounds, and the vectors that utilize these substrates for breeding and feeding $(3,16)$ together with physical conditions such as $\mathrm{pH}$ and temperature. Yeasts are associated with sugary substrates in nature, and they colonize flowers, fruits, tree exudates, leaves, mushrooms, animals, soil, etc. (3). The majority of yeast species has specialized habitats, and it is possible to isolate these microorganisms of different natural substrates in the geographical areas where they occur $(9,16)$.

Yeasts are immotile organisms, which need to be carried by vectors, mainly insects. Extensive studies have isolated yeasts associated with insects, mainly Drosophila spp. $(3,4,9)$. These flies are recognized as important vectors of yeasts, which are a major food source for adult and larval stages of the flies $(2,3,9)$. Some ecological works were done on yeast communities associated with Drosophila spp. in Atlantic Rain Forests of
São Paulo and Rio de Janeiro (10-12), and associated with fruits $(1,18)$. The Atlantic rain forest ecosystem represents one of the areas of the planet with the greatest biodiversity and is considered the second most threatened tropical forest among 15 regions recognized as hot spots (13). Studies of yeast diversity may reveal the effect of disturbance in the ecosystem at the species level and could result in new taxa and strains with potential biotechnological applications. Data comparisons on yeast communities from different Atlantic rain forest sites are important to understand the patterns of distribution of microbial communities in this ecosystem. In this work, we have studied the yeast communities associated with Drosophila spp., decaying fruits, mushrooms and tree exudates in two Atlantic rain forest fragments of the state of Minas Gerais, Brazil.

\section{MATERIALS AND METHODS}

Samples were collected from the two Atlantic rain forest sites. Rio Doce State Park is the most preserved fragment of Atlantic rain forest in state of Minas Gerais comprising 36,113.6

*Corresponding Author. Mailing address: Laboratório de Microbiologia Ambiental e Biotecnologia - Universidade Federal do Tocantins, Palmas, TO, Brasil. 
ha, and it is situated $248 \mathrm{~km}$ from the city of Belo Horizonte, in the region known as Vale do Aço, near the cities of Dionísio, Mariléia and Timóteo, between $19^{\circ} 58^{\prime}$ Lat. S and $42^{\circ} 62^{\prime}$ Long. W. The Ecological Station of Universidade Federal de Minas Gerais (UFMG) is situated in Belo Horizonte, and represents an urban forest fragment with 150 ha. Yeasts were collected from Drosophila flies, decaying fruits, mushrooms and tree exudates, in 2000 and 2001. Approximately $0.1 \mathrm{~g}$ of samples of fruits, tree exudates and mushrooms were collected aseptically, added to tubes with $1 \mathrm{ml}$ of sterile distilled water, and cultured a few hours after sampling. One loopfull was streaked on yeast extractmalt extract agar (YMA, $1 \%$ glucose, $0.5 \%$ peptone, $0.3 \%$ malt extract, $0.3 \%$ yeast extract, $2 \%$ agar) supplemented with 100 $\mathrm{mg} / \mathrm{l}$ of chloramphenicol. Adult flies of Drosophila spp. were captured from fruit or mushroom surfaces using sterile plastic bags, or with traps containing fermented banana as described by Tidon and Sene (21) modified by Morais et al. (11) for aseptic collection of yeasts. Vectored yeasts were isolated from 264 adult flies by allowing each individual fly to walk for $30 \mathrm{~min}$ on a plate containing YMA. Two hundred and seven flies were collected from Rio Doce State Park and 57 from site Ecological Station of UFMG. Yeasts grown on these plates should also include as minor components yeasts regurgitated by the flies and viable yeasts in fecal pellets. Another 180 flies were surface sterilized in the field by immersion in $70 \%$ ethanol for $1 \mathrm{~min}$ and transported to the laboratory within 2 hours on ice in tubes containing sterile distilled water. One-hundred and eighteen flies were obtained from Rio Doce State Park and 62 from Ecological Station of UFMG. These flies had their crops aseptically dissected from them, and they were streaked individually on YMA plates. Plates were incubated at room temperature $\left(25+3^{\circ} \mathrm{C}\right)$ for 5 to $7 \mathrm{~d}$. Individual yeast colonies of each morphotype were selected, brought into pure culture, and characterized by standard methods (23). Identities were verified using the keys of Kurtzman and Fell (5) and recent publications on description of new yeast species.

Identification of some prevalent yeast species with uncertain identity were confirmed by sequencing the D1/D2 variable domains of the large subunit rDNA. D1/D2 divergent domains were amplified by PCR as described by Lachance et al. (6) using the primers NL-1 (5'-GCATATCAATAAGCGGAGGAAAAG-3') and NL-4 (5'-GGTCCGTGTTTCAAGACGG-3'). The D1/D2 variable domains of the large subunit rDNA were amplified by polymerase chain reaction (PCR) from whole cells as described previously $(6,7)$. The amplified DNA was concentrated and cleaned on QIAquick PCR columns (Qiagen, Chatsworth, CA, USA), and sequenced in an ABI sequencer at the John P. Robarts Research Institute, London, ON, Canada. The sequences were edited with the program DNAMAN, version 4.0 (Lynnon BioSoft, Vandreuil, QB, Canada). Existing sequences for type and other strains of the yeast species were retrieved from GenBank.

\section{Yeast similarity measurement}

Similarity of yeast communities between forest fragments was calculated using the Sörensen index, based on presence/ absence of each yeast species in each forest fragment.

\section{RESULTS AND DISCUSSION}

\section{Yeast diversity}

Six hundred and eighteen samples were collected for yeast isolation (476 samples from Rio Doce State Park and 142 from Ecological Station of UFMG). A total of 608 yeast isolates were obtained corresponding to 71 different yeast species (Table 1). Fifth-five yeast species were isolated from Rio Doce State Park samples, being 33 species restricted to this forest fragment. In Ecological Station of UFMG, 38 yeast species were isolated, with 16 species restricted to substrates of this region. Twenty-two yeast species were common to the two forest fragments. The species richness was higher in Rio Doce State Park than Ecological Station of UFMG, and this result was expected because the first area represents an undisturbed forest fragment with a greater availability of resources for yeasts that included mushrooms and tree exudates besides the fruits also encountered in Ecological Station of UFMG. This site is an urban forest with a high degree of deforestation (8) that probably diminishes available resources as shown by the lower number of samples from Ecological Station of UFMG when compared to Rio Doce State Park. Morais et al. (11) have suggested that anthropogenic activities in forest fragments decrease yeast species richness in the disturbed areas. Similarity of yeast species among the two areas was low $(48.35 \%)$ probably due to different indigenous yeasts communities colonizing substrates in each area.

Yeasts isolated from Drosophila flies could represent the richness of yeast populations present in the habitats visited by the flies (9). The lower yeast species richness for flies collected in Ecological Station of UFMG probably indicates a low number of substrates visited in this site in comparison with Rio Doce State Park forest fragment. Forty-two yeast species were isolated from Drosophila surfaces at Rio Doce State Park forest, while twentyfive were isolated from Ecological Station of UFMG. In relation to yeast species isolated from Drosophila crops, the numbers of species were similar between the Rio Doce State Park and Ecological Station of UFMG, with 27 and 28 species, respectively (Table 1). The lower yeast richness in crops of flies than in surfaces from Rio Doce State Park samples, and similar number of yeast species in Drosophila crops from both sites may be indicative of food preferences among the flies, as stated by Morais et al (11). Candida natalensis, C. railenensis and Kloeckera apiculata were the yeast species more frequently isolated from Drosophila surfaces and crops in Rio Doce State Park forest fragment. In Ecological Station of UFMG, Pichia guilliermondii, P. kluyveri, C. sorboxylosa and P. membranifaciens were most frequently associated with the flies. In general, the yeast species more 
Tabela 1. Frequency of occurrence of yeast species isolated from mushrooms, fruits, tree exudates, Drosophila surfaces and Drosophila crops of two Atlantic rain forest fragments in state of Minas Gerais, Brazil.

\begin{tabular}{|c|c|c|c|c|c|c|c|c|c|}
\hline \multirow{2}{*}{$\begin{array}{c}\text { Yeast } \\
\text { species }\end{array}$} & \multicolumn{4}{|c|}{$\begin{array}{c}\text { Rio Doce State Park } \\
n=476\end{array}$} & \multicolumn{4}{|c|}{$\begin{array}{l}\text { Ecological Station of UFMG } \\
\qquad \mathrm{n}=142\end{array}$} & \multirow[t]{2}{*}{ TOTAL } \\
\hline & $\begin{array}{l}\text { Mushrooms } \\
\qquad(\mathrm{n}=78)\end{array}$ & $\begin{array}{l}\text { Fruits } \\
(\mathrm{n}=10)\end{array}$ & $\begin{array}{c}\text { Tree } \\
\text { exudates } \\
(n=63)\end{array}$ & $\begin{array}{c}\text { Drosophila } \\
\text { surfaces } \\
(\mathrm{n}=207)\end{array}$ & $\begin{array}{c}\text { Drosophila } \\
\text { crops } \\
(\mathrm{n}=118)\end{array}$ & $\begin{array}{l}\text { Fruits } \\
(n=23)\end{array}$ & $\begin{array}{c}\text { Drosophila } \\
\text { surfaces } \\
(\mathrm{n}=57)\end{array}$ & $\begin{array}{c}\text { Drosophila } \\
\text { crops } \\
(\mathrm{n}=62)\end{array}$ & \\
\hline Aureobasidium pullulans & 1 & & & 1 & & & & & 2 \\
\hline Candida bombicola - like & & & & 2 & & & & & 2 \\
\hline C. boidinii & & & & 1 & & 1 & 2 & 2 & 6 \\
\hline C. castellii & & & & & & & & 2 & 2 \\
\hline C. castellii - like $\mathrm{a}^{\mathrm{a}}$ & & & 1 & 1 & & & & & 2 \\
\hline C. catenulata & & & & & 1 & & & & 1 \\
\hline C. cylindracea $^{\mathrm{b}}$ & & 1 & & 1 & 4 & & 2 & 2 & 10 \\
\hline C. diversa & & & & 1 & & & 1 & 2 & 4 \\
\hline C. famata & & & & 2 & 1 & & 1 & & 4 \\
\hline C. famata - like $^{\mathrm{a}}$ & & & & & 1 & & & & 1 \\
\hline C. fructus & & & & & & & & 1 & 1 \\
\hline C. haemulonii - like ${ }^{\mathrm{a}}$ & & & & 1 & & & & & 1 \\
\hline C. homilentoma - like ${ }^{a}$ & & & & & 1 & & & & 1 \\
\hline C. kruisii & & & & 1 & & & & & 1 \\
\hline C. krusei & & & & & & 1 & & 1 & 2 \\
\hline C. magnoliae - like ${ }^{\mathrm{a}}$ & & & & 1 & & & & & 1 \\
\hline C. naeodendra-like ${ }^{\mathrm{a}}$ & & & & 1 & & & & & 1 \\
\hline C. natalensis ${ }^{\mathrm{b}}$ & & 3 & & 40 & 24 & & & & 67 \\
\hline C. parapsilosis & 1 & & & 4 & & & & & 5 \\
\hline C railenensis $\mathrm{b}$ & & 6 & & 46 & 22 & & 1 & & 75 \\
\hline C. restingae & & & & 3 & & & & & 3 \\
\hline C. rugosa & & & & & & & 2 & 1 & 3 \\
\hline C. sonorensis - like $^{\mathrm{a}}$ & & & & & & & & 1 & 1 \\
\hline C. sorbophila & & & & & & 2 & & & 2 \\
\hline C. sorbophila - like a & & & & 1 & & & & & 1 \\
\hline C. sorboxylosa ${ }^{\mathrm{b}}$ & & & 1 & 1 & & 3 & 13 & 23 & 41 \\
\hline C. sorboxylosa - like a & & & & & & & 1 & 1 & 2 \\
\hline C. stellata & & & & 3 & 1 & & & 2 & 6 \\
\hline C. versatilis & & & & 1 & & & & & 1 \\
\hline C. zeylanoides & & & & 1 & 1 & & & & 2 \\
\hline C. zeylanoides - like ${ }^{\mathrm{a}}$ & & & & & 1 & & 2 & 3 & 6 \\
\hline Candida sp. 1 & 1 & & & & & & & 1 & 2 \\
\hline Candida sp. 2 & & & 1 & 1 & & & 1 & & 3 \\
\hline Candida sp. 3 & & & & & & & 1 & & 1 \\
\hline Candida sp. 4 & & & & 1 & & & 1 & & 2 \\
\hline Candida sp. 5 & & & & & & & & 1 & 1 \\
\hline Candida sp. 6 & & & & & & & & 1 & 1 \\
\hline Cryptococcus flavus & & 1 & & 1 & 2 & & & & 4 \\
\hline Cr. albidus & & & & & & & 1 & & 1 \\
\hline Cr. humicolus ${ }^{\mathrm{b}}$ & 6 & 1 & 2 & 8 & & & & & 17 \\
\hline Cr. laurentii & 1 & & & & & & & & 1 \\
\hline Cr. yarrowii & 1 & & & 2 & 1 & & 1 & & 5 \\
\hline Cr. yarrowii - like & & & & 2 & 2 & & & & 4 \\
\hline
\end{tabular}


Debaryomyces hansenii

Galactomyces geotrichum ${ }^{\mathrm{b}}$

Geotrichum clavatum - like ${ }^{\text {a }}$

G. silvícola ${ }^{\mathrm{b}}$

Issatchenkia occidentalis

Kloeckera apiculata

K. apis

Kodamaea ohmeri

Metschnikowia sp. ${ }^{\text {b }}$

Myxozyma sp.

Pichia guilliermondii

P. kluyveri

P. kluyveri-like ${ }^{\mathrm{a}}$

P. membranifaciens

P. membranifaciens - like ${ }^{\mathrm{a}}$

$P$. silvicola

P. stipitis - like ${ }^{\mathrm{a}}$

Pseudozyma antarctica

P. antarctica - like ${ }^{\mathrm{a}}$

Saccharomyces bayanus

S. cerevisiae

S. exiguus

S. kluyveri

S. servazzii

S. unisporus - like ${ }^{\mathrm{a}}$

Saccharomycopsis crataegensis ${ }^{\mathrm{b}}$

Torulaspora delbrueckii

Zygoascos hellenicus - like ${ }^{\mathrm{a}}$
7

8

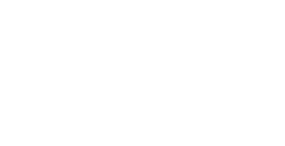

1

2

1

1

2

2

1

3

4

$\begin{array}{lll}1 & 5 & 1\end{array}$

2

2

19
8
1
1

8

5

6

1

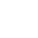

5

1

6

4

2

3

1

$2 \quad 18$

1

1

4

$1 \quad 1$

$\begin{array}{ll}7 & 36\end{array}$

(2)

1

$\begin{array}{ll}1 & -3 \\ 3 & -9\end{array}$

1

9

15

$14 \quad 40$

1

1

1

68

49

3

39

3

$\begin{array}{lll}1 & 6 & 9\end{array}$

124

121

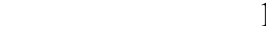

1

7

$1 \quad 1$

2

1

1

1

1

13

\begin{tabular}{llllllllll}
\hline Total & 12 & 17 & 13 & 209 & 90 & 24 & 94 & 149 & 608 \\
\hline
\end{tabular}

${ }^{\mathrm{a}}$ like $=$ species similar physiologically to the species indicated.

${ }^{\mathrm{b}}$ Species identity confirmed by sequencing of D1D2 domains of the large subunit of rDNA.

frequently isolated from Drosophila surfaces in each forest fragment were also isolated from the crops of flies. These yeast species inhabit fruits and flowers in forest environment (16), and could indicate the feeding substrates utilized by the flies in these forest fragments $(10,11)$.

The yeast communities associated with decaying fruits of both forest fragments were composed by yeast species frequently isolated from fruits $(16,22)$. Candida railenensis and C. natalensis were isolated from fruits in Rio Doce State Park forest fragment, but they were not isolated from fruits in Ecological Station of UFMG forest. Species of Kloeckera, Pichia and Candida were isolated from fruits of both forests. These data indicate that the yeast populations isolated from fruits in both forest fragments did not present great differences when compared with yeast communities present in fruits from other regions $(9,11)$.

Yeasts from mushrooms are extremely distinct from other yeast communities. Ramirez-Gomez (19) has isolated
Sporobolomyces albidus, Candida curvata, Saccharomyces cerevisiae, Torulopsis inconspicua and C. anomala from mushrooms. Phaff \& Knapp (15) have found C. humicola as prevalent yeast species in basidiocarps of Clavaria, Pleurotus and Podoscypha. These species were not found associated with the mushrooms studied in our work. Cr. humicolous was the yeast species more frequent associated with the mushrooms. Other yeast species were isolated in low frequency of occurrence. Although 78 mushroom samples were screened for yeast isolation, only a few yeast species were isolated. This result suggest that mushrooms are not a good substrate for yeast growth, or the methodology utilized for yeast isolation of yeasts from mushroom samples was not appropriate. Suh et al. (20) has shown a hyperdiverse yeast guild associated with the guts of beetles collected from basidiocarps in tropical and subtropical habitats and it is possible that this sampling strategy yields more isolates that direct sampling from substrates. Further studies comparing different methods and culture media are 
necessary to study yeasts associated with mushrooms in Atlantic Rain forest sites.

Yeast communities associated with tree exudates were composed mainly by $C r$. humicolous, P. membranifacies and $P$. membranifaciens-like. Most of the yeasts isolated from this substrate were also found in the other substrates studied. We have studied a high number of samples of tree exudates, and obtained nine species in low frequency of occurrence. Contamination of the isolation plates with molds inhibited yeast growth in several samples. Probably, enrichment methodologies or substances to inhibit mold growth could be useful to study yeast populations associated with this substrate.

A new species of Geotrichum, G. silvicola, was isolated from Drosophila surfaces and crops in both forest fragments (17). An undescribed Metschnikowia species was isolated from Drosophila surface at Rio Doce State Park. Yeast species related to infections in animals such as C. krusei, C. parapsilosis e C. castellii were also isolated from both forest fragments. Saccharomyces cerevisiae isolates were obtained from Drosophila and tree exudates samples at Rio Doce State Park forest fragment. This species has industrial importance, and wild isolates are difficult to obtain from forest environment. Morais et al. (10) have isolated three isolates of S. cerevisiae from forests in Rio de Janeiro. However, two of these isolates were described as a new yeast species, named $S$. cariocanus (14). Molecular studies are necessary to confirm if our strains are $S$. cerevisiae or S. cariocanus, or a new Saccharomyces species.

\section{ACKNOWLEDGEMENTS}

This work was funded by the Conselho Nacional de Desenvolvimento Científico e Tecnológico of Brazil (CNPq), Fundação ao Amparo a Pesquisa de Minas Gerais (FAPEMIG). We acknowledge the cooperation of Luiz Henrique Rosa and Marcelo Guedes de Brito during samplings.

\section{RESUMO}

\section{Comunidades de leveduras em dois fragmentos de Mata Atlântica no sudeste do Brasil}

O objetivo deste trabalho foi estudar as comunidades de leveduras associadas a frutos, cogumelos, exudatos de árvores e moscas do gênero Drosophila, em dois fragmentos de Mata Atlântica no Estado de Minas Gerais, Brasil. Foram coletadas 456 amostras no Parque Estadual do Rio Doce e 142 na Estação Ecológica da Universidade Federal de Minas Gerais. Destas amostras foram obtidas 608 isolados de levedura, distribuídas em 71 espécies. Entre os isolados obtidos a partir do Parque Estadual do Rio Doce, 17 foram provenientes de frutos, 12 de cogumelos, 13 de exudatos de árvores e 299 de Drosophila spp. A Estação Ecológica da Universidade Federal de Minas Gerais possibilitou a obtenção de 24 isolados de frutos e 243 de Drosophila spp. Foram observadas comunidades distintas de leveduras associadas a Drosophila, frutos, cogumelos e exudatos de árvores. O maior número de espécies foi obtido em drosófilas, sugerindo que estas moscas são vetores naturais destes microrganismos.

Palavras-chave: Comunidades de leveduras, Drosophila, frutos, cogumelos, exudatos de árvores, Mata Atlântica.

\section{REFERENCES}

1. Abranches, J.; Vital, M.J.S.; Starmer, W.T.; Mendonça-Hagler, L.C.; Hagler, A.N. (2000). The yeast community and mycocin producers of guava fruit in Rio de Janeiro, Brazil. Mycologia. 92 (1), 16-22.

2. Begon, M. (1982). Yeasts and Drosophila. In The genetics and biology of Drosophila, M. Ashburner, H.L. Carson, and J.N. Thompson (eds.). Academic Press, London, U.K., p. 345-384.

3. Ganter, P.F. (2006). Yeast and invertebrate associations. In Biodiversity and Ecophysiology of Yeasts, The Yeast Handbook, first edn, pp. 303-370. Edited by C. A. Rosa \& G. Peter. Heidelberg: Springer.

4. Gomes, L.H.; Echeverrigaray, S.; Conti, J.H.; Lourenço, M.V.M.; Duarte, K.M.R. (2003). Presence of the yeast Candida tropicalis in figs infected by the fruit fly Zaprionus indianus (Dip.: Drosophilidae). Braz. J. Microbiol. 34, 5-7.

5. Kurtzman, C.P.; Fell, J.W. (1998). The yeasts: a taxonomic study. Fourth Revised and Enlarged Edition. Elsevier, Amsterdam.

6. Lachance, M.A.; Bowles, J.M.; Starmer, W.T.; Barker, J.S.F. (1999). Kodamaea kakaduensis and Candida tolerans, two new ascomycetous yeast species from Australian Hibiscus flowers. Can. J. Microbiol. 45, 172-177.

7. Lachance, M.A.; Daniel, H.M.; Meyer, W.; Prasad, G.S.; Gautam, S.P.; Boundy-Mills, B. (2003). The D1/D2 domain of the largesubunit rDNA of the yeast species Clavispora lusitaniae is unusually polymorphic. FEMS Yeast Res. 4, 253-258.

8. Lombardi, J.A.; Temponi, L.G.; Leite, C.A. (1999). Mortality and diameter growth of lianas in a semideciduous forest fragment in Southeastern Brazil. Acta Bot. Brasílica. 13, 159-165.

9. Morais P.B.; Pagnocca F.C.; Rosa C.A. (2006). Yeast communities in tropical rain forests in Brazil and other South American ecosystems. In Biodiversity and Ecophysiology of Yeasts, The Yeast Handbook, first edn, pp. 461-484. Edited by C. A. Rosa \& G. Peter. Heidelberg: Springer-Verlag.

10. Morais, P.B.; Hagler, A.N.; Rosa, C.A.; Mendonga-Hagler, L.C.; Klaczko, L.B. (1992) Yeasts associated with Drosophila in tropical forests of Rio de Janeiro, Brazil. Can. J. Microbiol. 38, 1150-1155.

11. Morais, P.B.; Martins, M.B.; Hagler, A.N.; Klaczko, L.B.; MendonçaHagler, L.C. (1995). The yeast succession in the amazonic Parahancornia amapa fruit as resource partitioning among Drosophila. Appl. Environ. Microbiol. 61, 4251-4257.

12. Morais, P.B.; Rosa, C.A.; Hagler, A.N.; Mendonçahagler, L.C. (1994). Yeast communities of the cactus Pilosocereus arrabidae as resources for larval and adult stages of Drosophila serido. Antonie van Leeuwenhoek, 66: 313-317.

13. Myers, N.; Mittermeier, R.A.; Mittermeier, C.G.; da Fonseca, G.A.B.; Kent, J. (2000). Biodiversity hotspots for conservation priorities. Nature. 403, 853-858.

14. Naumov, G.I.; James, S.A.; Naumova, E.S.; Louis, E.J.; Roberts, I. N. (2000). Three new species in the Saccharomyces sensu stricto complex: Saccharomcyes cariocanus, Saccharomyces kudriavzevii 
and Saccharomyces mikatae. Int. J. Syst. Evol. Microbiol. 50, 19311942.

15. Phaff, H.J.; Knapp, E.P. (1956). The taxonomy of yeasts found in exudates of certain trees and other natural breeding sites of some species of Drosophila. Antonie van Leeuwenhock J. Microbiol., v. 22 , p. $117-130$.

16. Phaff, H.J.; Starmer, W.T. (1987) Yeasts associated with plants, insects and soil. In: The Yeasts, Vol. 1: Biology of Yeasts (Rose, A.H. and Harrison, J.S., Eds.), Academic Press, London.

17. Pimenta, R.S.; Alves, P.D.D.; Corrêa, Jr. A.; Lachance, M.A.; Prasad, G.S.; Sinhá, R.B.R.R.P.; Rosa, C.A. (2005). Geotrichum silvicola sp. nov., a novel asexual arthroconidial yeast species related to the genus Galactomyces. Int. J. Syst. Evol. Microbiol. 55, 497-501.

18. Prada, G.M.M.; Pagnocca, F.C. (1997). Ascomycetous yeasts associated with naturally occurring fruits in a tropical rain forest. Folia Microbiol. 42, (1), 39-46.
19. Ramirez-Gomez, C. (1957). Contribucion al estudio de la ecologia de las levaduras I. Estudio de levaduras aisladas de hongos carnosos. Microbiol. Espanola. 10, 215-247.

20. Suh, S.O.; McHugh, J.V.; Pollock, D.D.; Blackwell, M. (2005). The beetle gut: a hyperdiverse source of novel yeasts. Mycol. Res. 109, 261-265.

21. Tidon, R.; Sene, F.M. (1988). A trap that retains and keep Drosophila alive. Dis., 67, 89.

22. Trindade, R.C.; Resende, M.A.; Silva, C.M.; Rosa, C.A. (2002) Yeasts associated with fresh and frozen pulps of Brazilian tropical fruits Syst. Appl. Microbiol. 25, 294-300.

23. Yarrow, D. (1998). Methods for the isolation, maintenance and identification yeasts. In: Kurtzman, C.P.; Fell, J.W.(eds). The yeasts - a taxonomic study. 4rd ed. Elsevier Science Publ. B.V. Amsterdam, the Netherlands. 